is only one quarter of the value of the revenue for that intervening period-and if for 28 years the value of the revenue is double that of the capital. It will thus be obvious of how little consequence the present selling value of such an investment is, and how little also any not very material change in its selling price at the periods contemplated for its realisation, will affect the present value.

It is believed to be the custom for manyAssurance Offices, at an investigation, to value permanent and terminable annuities at the price they will bring on the average price for a short time previous; but the propriety of this is much to be doubted, indeed, it rather tends in the opposite direction to the truth. Composed, as a considerable portion of the funds of an assurance office is likely to be, of mortgages producing a variable rate of interest, when the interest on them is reduced the selling prices of permanent and terminable annuities are of course likely to rise, and if estimated accordingly, the effect is to show a profit on those funds, while in fact, the office, looking to the general return on its whole investments, would be essentially poorer; indeed, when the mortgages were producing a high rate of interest, there would be more propriety in estimating the permanent investments at the high value, although, of course, the selling price was then likely to be low.

Upon the whole, it seems clear, that the selling price is no proper criterion of the value at which investments of that nature should be estimated, where there is no intention of early realisation. Let the security for the annual returns be narrowly enquired into; if that be undoubted, then the proper way seems to be to estimate its value, if not altogether according to the rate of interest assumed by the office, more with reference to this criterion, than by a method which tends to increase the value at that rate, at a time when the average return on the whole capital is falling, and that general capital is hence less valuable in respect of its return, and which leads to a diminution in the value when it is well fortified by the general capital, yielding an enhanced revenue.

$$
\begin{array}{rr}
\text { Glasgow, 20th Dec., } 1850 . & \text { I am, } 8 \mathrm{c.}, \\
\text { W. S. }
\end{array}
$$

\title{
ON THE FRENCH LIFE ASSURANCE COMPANIES.
}

\section{To the Editor of the Assurance Magazine.}

SIR,-In the first number of your Magazine I observed that a slight sketch was given of the "Life Assurance Companies in France."

Our Actuaries at home are so occupied in these days of intense competition among Assurance Companies, in endeavouring to promote the objects of their own offices, and necessarily in watching the progress of competing Companies, that they have but little leisure to enquire what their neighbours on the other side of the Channel are doing.

Public attention, however, having been now called to this subject by the article just mentioned, some further enquiry into the system of business pursued by the French Companies, may not, perhaps, be uninteresting either to the general reader or to the Actuary.

That Life Assurance in France has been adopted from the English, and is still in its infancy there, the principal French Companies agree in allowing, as the following extracts clearly show.

The prospectus of "L'Union" speaks in its introductory article on the subject of life Assurance as follows:-

- . . "Mais il est une de ses branches peu connue encore en France.

- . . Cette création, qui seule suffirait pour caractériser le génie d'une nation, remonte en Angleterre aux premières années du XVIIIe siècle." And again-" En France, les Assurances sur la vie sont bien loin d'avoir acquis un semblable développement."

"La Compagnie d'Assurances Générales sur la Vie," established about the year 1820, also states as follows:-

"Les $A$ ssurances sur la vie, qui existent depuis plus d'un Siècle en Angleterre, sont encore dans leur enfance parmi nous."

It appears from the prospectuses of the French companies that their business 
at present is principally confined to absolute Whole Life Assurances, and Assurances for terms of years, on single or on two or more lives, and to Survivorship Assurances.

They do not seem to have yet adopted our multifarious modes of granting Assurances. And, indeed, if sufficient business can be obtained on the more simple plan, it is highly desirable to avoid all complications of a science already sufficiently complex; and it is well known that the transactions of those London offices whose standing is the highest, have almost entirely been confined to those classes of Assurances just mentioned.

The conditions of the different French offices appear to be very similar to those of our own respectable offices.

The only novel feature, and one which does not seem to have been as yet held out as an inducement to the British public* (though, in point of fact, the same advantages would, on application, be granted by many London offices,) is that of reducing the sum assured in default of payment of the premium within a certain period after the same becomes due, according to a scale agreed upon before the Assurance is effected, provided only that the Policy has been in force a certain number of years.

The following are the words of "L'Union" on this subject:-

"La prime est payable d'avance au domicile de la Compagnie. Elle est due au jour fixé par la présente, elle doit être acquittée au plus tard dans les trente jours qui suivent."

"A défaut de payment dans ce dêlai, la somme assurée est, et demeure réduite dans la proportion determinée au Tableau ci joint, et l'assuré n'est plus tenu à aucun versement pour les années ̀̀ venir, cependant et par exception au paragraphe précédent, si la Police a moins de trois ans de durée, l'assurance est annulée en totalité.

TABLEAU.

Somme a laquelle se reduit une Assurance de 100 francs à défaut de payement de la Prime après un certain nombre d'années révolues.

\begin{tabular}{c|c|c|c|c|c|c}
\hline $\begin{array}{c}\text { Age á la } \\
\text { Date de la } \\
\text { Police. }\end{array}$ & $\begin{array}{c}\text { Aplès } \\
5 \text { Aus. }\end{array}$ & $\begin{array}{c}\text { Après } \\
10 \text { Ans. }\end{array}$ & $\begin{array}{c}\text { Après } \\
15 \text { Ans. }\end{array}$ & $\begin{array}{c}\text { Après } \\
20 \text { Ans. }\end{array}$ & $\begin{array}{c}\text { Après } \\
25 \text { Ans. }\end{array}$ & $\begin{array}{c}\text { Après } \\
30 \text { Ans. }\end{array}$ \\
\cline { 1 - 2 } 30 & 12.16 & 24.05 & 35.60 & 46.49 & 56.38 & 65.08 \\
40 & 15.21 & 29.54 & 42.57 & 54.02 & 63.78 & 7191 \\
50 & 18.49 & 34.74 & 48.61 & 60.13 & 69.35 & 75.97 \\
60 & 21.25 & 38.91 & 53.04 & 63.18 & - & - \\
\hline
\end{tabular}

At first sight this plan has an ad captandum appearance; but, upon consideration, many objections will appear: among which not the least would be the difficulty of securing against the life assured, (after the policy has been reduced in value, and the assured relieved from all future premiums), without the knowledge of the Company, leaving Europe for an unhealthy district, and returning with his health and constitution shattered, to die in his native land.

The same objection, it is true, is open to all single premium assurances; but, on the other hand, these are for the most part effected by persons of standing in independent circumstances, and who can be more relied upon than those who, from want of means, may be compelled to abandon their original policies.

The Table given below, shows the premiums for assurances for one year, and for the whole of life, required by tive of the principal French Companies in juxta-position with five of the most respectable English Companies; by which it appears, that their rates compare very favourably with the English Companies of known standing.

* Since writing the above, I have seen the prospectus of the United Service and General Life Assurance Association, and find therein a notification of a similar scheme. $-H . W . P$. 
The five Companies chosen for this comparison, have been taken indiscriminately, and from their rates being all identical, it is reasonable to suppose that they represent the average premiums charged by the French Companies.

Table, showing the Annual Premiums required by certain French and Euglish Companies, for the Assurance of $£ 100$ on a single Life:-

\begin{tabular}{|c|c|c|c|c|c|c|c|c|}
\hline \multirow{3}{*}{ Ages. } & \multirow{2}{*}{\multicolumn{2}{|c|}{ French Companies. }} & \multicolumn{6}{|c|}{ English Companies. } \\
\hline & & & \multicolumn{2}{|c|}{ Royal Exchange. } & \multicolumn{2}{|c|}{ London Assurance. } & \multicolumn{2}{|c|}{ Alliance. } \\
\hline & One Year & $\begin{array}{c}\text { Whole of } \\
\text { Life. }\end{array}$ & One Year. & $\begin{array}{c}\text { Whole of } \\
\text { Life. }\end{array}$ & One Year & $\begin{array}{c}\text { Whole of } \\
\text { Life. }\end{array}$ & One Year. & $\begin{array}{c}\text { Whole of } \\
\text { Life. }\end{array}$ \\
\hline 30 & $\begin{array}{ccc}£ & \text { s. } & \text { d. } \\
1 & \text { Il } & 0\end{array}$ & $\begin{array}{lll}£ & \text { s. } & \text { d. } \\
2 & 9 & 10\end{array}$ & $\begin{array}{lll}\boldsymbol{E} & \mathrm{s} . & \mathrm{d} \\
1 & 13 & 3\end{array}$ & $\begin{array}{lll}\boldsymbol{E} & \mathrm{s} . & \mathrm{d} \\
2 & 13 & 3\end{array}$ & $\begin{array}{lll}£ & \text { s. } & . \\
1 & 8 & 9\end{array}$ & $\begin{array}{lll}\boldsymbol{E} & \text { s. } & \text { d. } \\
2 & 11 & 11\end{array}$ & $\begin{array}{ccc}\text { E } & \text { s. } & \text { d. } \\
1 & 6 & 9\end{array}$ & $\begin{array}{lll}\text { \& } & \text { s. } & \text { d. } \\
2 & 9 & 2\end{array}$ \\
\hline 40 & 11710 & $\begin{array}{lll}3 & 5 & 8\end{array}$ & $\begin{array}{lll}2 & 0 & 9\end{array}$ & $\begin{array}{lll}3 & 8 & 0\end{array}$ & $\begin{array}{lll}111 & 7\end{array}$ & $\begin{array}{lll}3 & 7 & 0\end{array}$ & $\begin{array}{lll}113 & 7\end{array}$ & $\begin{array}{lll}3 & 6 & 6\end{array}$ \\
\hline 50 & $212 \quad 0$ & $\begin{array}{lll}4 & 13 & 3\end{array}$ & 2150 & $410 \quad 9$ & $\begin{array}{lll}1 & 19 & 6\end{array}$ & 4161 & 2109 & 4142 \\
\hline 60 & $\begin{array}{lll}4 & 6 & 0\end{array}$ & $\begin{array}{lll}7 & 2 & 8\end{array}$ & $\begin{array}{lll}318 & 0\end{array}$ & $\begin{array}{lll}6 & 7 & 3\end{array}$ & $\begin{array}{lll}3 & 10 & 2\end{array}$ & $\begin{array}{lll}7 & 3 & 8\end{array}$ & $\begin{array}{lll}4 & 3 & 7\end{array}$ & 71411 \\
\hline
\end{tabular}

The French Companies alluded to above, are, La Compagnie d'Assurances Generales (Established 1818); L'Union, (1829); La Nationale, (1830); La France, (1843); Le Phénix, (1846); each of which charges the same premiums as the others, both for one year and the whole of life.

It will be seen that the rates in question both for one year, and for the whole of life agree very nearly with those charged by the Alliance Assurance Company of London, whose rates, founded as they are upon the Carlisle mortality*, which is supposed to give a correct view of human life, may be considered to be as nearly equitable as possible.

From these circumstances, and from the fact that our neighbours do not ap. pear to be attempting any dangerous experiments in Life Assurance, there is every reason to consider that their Offices, if well conducted, and prudently managed, are, to say the least, very superior to many of the new English Companies, with the announcement of whose novel plans the advertising columns of our newspapers are daily burthened.

Alliance Assurance Company, Nov. 2nd, 1850.

I remain, \&c.

H. W. PORTER.

\section{ON THE COMPARATIVE ADVANTAGES OF THE OLD AND THE NEW METHOIS OF COMPUTATION. \\ To the Editor of the Assurance Magazine.}

Sir,-I shall be glad if you can make room for the following remarks. The distinction between the old and the new methods of computation in Life Contingencies, consists in the different nature of the data which they respectively supply for the solution of practical questions. The principle on which all such questions are solved, is to found an equation between the present values of the benefits to be purchased and the payments to be given for if, using a symbol for the unknown amount of the one or the other, as the case may be. The solution of this equation, which is always of the simplest kind, then gives the value of the symbol employed for the unknown amount. Or if symbols be used for both amounts, the equation will then be of a more general kind, and

* The rates of premium given in the Table as those of the Royal Exchange, are the Northampton rates, still used by the Equitable Society, and many of the older Companies. These rates of the Alliance appear to be deduced from the Carlisle Tables at 4 per cent, with 40 per cent. added. The premiums charged by the French Companies approximate still more nearly for the whole continuance of life, to those obtained from Farr's English Life Table, (census 1841), at 3 per cent.. with 20 per cent. added to the pure premium, as may be noticed in the following com-

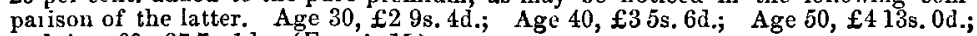
and Age $60, \pm 77 \mathrm{~s}, 1$ d. $-\left(\mathrm{ED}_{\mathrm{D}}, A . M\right)$ 